\title{
Macrophage migration inhibitory factor levels correlate with an infection in trauma patients
}

\author{
Young-Duck Cho, M.D., ${ }^{1}$ Sung-Hyuk Choi, M.D., ${ }^{1}$ Jung-Youn Kim, M.D., ${ }^{1}$ Sung-Jun Park, M.D., ${ }^{1}$ \\ Young-Hoon Yoon, M.D., ${ }^{1}$ Han-Jin Cho, M.D., ${ }^{2}$ Ji-Won Yeom, M.D. ${ }^{3}$ \\ ${ }^{1}$ Department of Emergency Medicine, Korea University Guro Hdspital, Seoul-South Korea \\ ${ }^{2}$ Department of Emergency Medicine, Korea University Ansan Hospital, Ansan, Kyunggi-do-South Korea \\ ${ }^{3}$ College of Medicine, Korea University, Seoul-South Korea
}

\begin{abstract}
BACKGROUND: The role of migration inhibitory factor (MIF) is best understood in septic shock and septic disease; however, the role of MIF in a secondary infection after trauma has not yet been completely studied. This study aimed to evaluate the role of MIF in trauma patients.

METHODS: The patients in the study population were divided into two groups according to the results of their MIF levels. The initial MIF levels, trauma mechanism, revised trauma score, survival rate, length of stay (LOS) in the intensive care unit (ICU), level of leukocytes, and level of C-reactive protein (CRP) were compared between the groups.

RESULTS: Overall, II 6 patients were enrolled from August I, 2014 to July 3I, 20I5. LOS in ICU in the elevated MIF group was $5.67 \pm 7.54$ days compared with $2.09 \pm 2.26$ days in the normal MIF group. Further, CRP level in the elevated MIF group was higher than that in the normal MIF group.

CONCLUSION: In a place such as the department of emergency medicine, it is critical and important for emergency physicians to make a proper judgment and to prepare for the worst scenario. Therefore, the utilization of MIF level in trauma patients has a possibility for assisting emergency physicians.
\end{abstract}

Keywords: Infection; macrophage migration inhibitory factor; trauma.

\section{INTRODUCTION}

In innate and acquired immune responses, migration inhibitory factor (MIF) plays a critical role as a pleiotropic cytokine and critical mediator. ${ }^{[1]}$ About 50 years ago, it was the first cytokine that was discovered. ${ }^{[2]}$ With the identification of the CXC chemokine receptors 2 (CXCR2) and 4 (CXCR4), it became possible to identify MIF's function in promoting the directed migration and recruitment of leukocytes into infectious and inflammatory sites such as a chemokine-like cytokine. ${ }^{[3,4]}$ MIF is commonly expressed in both immune and

Address for correspondence: Sung-hyuk Choi, M.D.

148, Gurodong-ro, Guro-gu, 08308 Seoul - South Korea

Tel: 82। 0-5059-9090 E-mail: kuedchoi@korea.ac.kr

Ulus Travma Acil Cerrahi Derg

2017;23(3): 193-198

doi: $10.5505 /$ tjtes.2016.04780

Copyright 2017

TJTES non-immune cells. Stored in the pituitary gland, in T cells and macrophages, MIF reacts to various stimuli such as infection and stress. ${ }^{[5,6]}$ Most of the critical functions of MIF include macrophage function regulation, ${ }^{[7]}$ lymphocyte immunity, ${ }^{[8]}$ and endocrine function. ${ }^{[9-1 /]}$ It also counter-regulates the immunosuppressive and anti-inflammatory activities of glucocorticoids. ${ }^{[9,12,13]}$ In the pathogenesis of acute and inflammatory diseases, such as septic shock, rheumatoid disease, inflammatory lung disease, glomerulonephritis, and inflammatory bowel disease, MIF plays a critical role, as shown in studies using MIF-/- mice, recombinant MIF, and neutralizing anti-MIF antibodies. ${ }^{[14-16]}$ MIF is best understood with regard to its role in septic shock and septic disease. Mice with a genetic deletion of the Mif gene were protected from endotoxin shock, gram-negative septic shock, and gram-positive toxic shock. ${ }^{[16-19]}$ Nevertheless, the relationship between trauma patients and MIF levels has not been clearly established. Cellular immune function suppressed by trauma can lead to sepsis, multi-organ failure, and even death. Patients with severe trauma are vulnerable to infection and, in turn, have a high risk of mortality. MIF has important roles in several immune responses such as the modulation of numerous 
cytokines, and it is considered to play a major part in the pathophysiology of septic shock and chronic inflammation. ${ }^{[20]}$ However, MIF's role in traumatic conditions has not yet been determined.

In this study, we aimed to investigate the specific role of MIF levels in the infection risk in trauma patients. We designed a prospective study of trauma patients in our emergency department (ED). We compared MIF levels in trauma patients with a number of indicators related to an infection, such as fever, c-reactive protein (CRP), length of stay (LOS) in the intensive care unit (ICU), injury severity score (ISS), and revised trauma score (RTS).

\section{MATERIALS AND METHODS}

\section{Study Design and Setting}

The study protocol and written informed consent form were reviewed and approved by Korea University Guro Hospital (institutional review board No. 11017). This study had a single center, with a prospective cohort study design. It was performed in a level I academic trauma center located in the metropolitan area of Seoul, South Korea from August I, 2014 to July 3I, 2015.

\section{Study Group}

Overall, II6 patients participated in this prospective study. The inclusion criteria were blunt or penetrating trauma in patients who were $>18$ years and were transported to our ED by the emergency medical service and required a whole-body CT and trauma team activation. The initial clinical assessment and decision were made by a board-certified attending emergency physician. The physician's decision was based on the American College of Surgeons Committee on Trauma criteria for trauma triage.

\section{Study Parameters}

The trauma patients were divided into two groups: I) normal MIF group and 2) elevated MIF group. The initial MIF levels, trauma mechanism, RTS, ISS, LOS in the ICU, and level of CRP were compared between the two groups. The patients' temperatures were taken at least four times (at 6:00 am, 12:00 pm, 6:00 pm, 12:00 am) during admission by a nurse using an infrared tympanic thermometer. Fever was defined as having a core body temperature $\geq 38.0^{\circ} \mathrm{C}(\mathrm{F})$.

\section{Samples}

\section{I) MIF}

Serum blood samples were collected within $2 \mathrm{~h}$ of arrival at ED and sent to the laboratory for MIF level measurement. Supernatants were collected after incubation for 2 or $20 \mathrm{~h}$. MIF concentration in the culture supernatants was measured by sandwich ELISA. Briefly, $2 \mu \mathrm{g} / \mathrm{ml}$ of monoclonal capture antibody (R\&D Systems, Minneapolis, MN, USA) was added to a 96-well plate and incubated for one day at room tempera- ture and washed with a buffer three times. After washing, the plates were incubated in a blocking solution of phosphatebuffered saline (PBS) containing I\% bovine serum albumin and $0.05 \%$ Tween-20 for $\mathrm{I} \mathrm{h}$ at room temperature and washed with a buffer three times. Test samples and standard recombinant MIF (R\&D Systems) were added to the plates and incubated for $2 \mathrm{~h}$ at $4^{\circ} \mathrm{C}$. The plates were washed three times with PBS containing Tween-20, $200 \mathrm{ng} / \mathrm{ml}$ of biotinylated detection monoclonal goat-antihuman antibodies (R\&D Systems) were added, and the plates were incubated for 2 $\mathrm{h}$ at room temperature. After washing thrice, streptavidinalkaline-phosphatase ( I:2000; Sigma-Aldrich Co.) was added, and the reaction was allowed to proceed for $20 \mathrm{~min}$ at room temperature. The plates were washed thrice, and I $\mathrm{mg} / \mathrm{ml}$ of p-nitrophenylphosphate dissolved in diethanolamine (SigmaAldrich Co.) was added to induce a color reaction which was stopped with $50 \mu$ l of I $\mathrm{M} \mathrm{NaOH}$. The optical density at 450 $\mathrm{nm}$ was measured on an automated microplate reader (BioRad Laboratories Inc., Hercules, CA, USA). A standard curve was generated by plotting the optical density versus the log of the MIF concentration. The experiments were conducted 10 times.

\section{2) CRP}

Serum blood samples were collected within $2 \mathrm{~h}$ after arrival at ED for a serum CRP analysis. The serum CRP concentrations were determined using a human turbidimetric immunoassay (human CRP turbidimetric immunoassay kit, Beckman Coulter, Inc., USA). Analyses were performed on an automated analyzer (IMMAGE 800, Beckman Coulter, USA) according to the manufacturer's instructions.

\section{Statistics}

For the statistical analysis, SPSS statistical software (SPSS, Inc., Chicago, IL, USA) was used. The mean and standard deviation, sensitivity, and specificity were used for data description. The means were measured with $95 \%$ confidence interval (Cl). Pearson's chi-squared test for categorical variables and an independent t-test were used for measuring continuous variables. The receiver operating characteristics (ROC) curve was used to assess the cutoff value of MIF levels in the patients with fever. The area under the ROC curve (AUC) of the sensitivity over I-specificity was determined to provide a numerical summary of the indicator's performance. $\mathrm{P}<0.05$ was considered significant.

\section{RESULTS}

Overall, 192 patients were enrolled, of which 76 patients were excluded from the study. Among those excluded, 20 patients had been transferred elsewhere, 36 had a trauma of an unknown origin, and 20 patients had been transferred from other hospitals. Among the 116 patients, 72 (62\%) had an elevated MIF level, and 44 (38\%) had a normal MIF level. The normal range of MIF levels was not clearly defined in 
Table I. General demographics

\begin{tabular}{|c|c|c|c|c|c|c|c|}
\hline \multirow[t]{2}{*}{ Variables } & \multicolumn{3}{|c|}{ Elevated MIF } & \multicolumn{3}{|c|}{ Normal MIF } & \multirow[t]{2}{*}{$\mathbf{p}$} \\
\hline & $\mathbf{n}$ & $\%$ & Mean士SD & $\mathbf{n}$ & $\%$ & Mean $\pm S D$ & \\
\hline Total & 72 & 62 & & 44 & 38 & & \\
\hline \multicolumn{8}{|l|}{ Sex } \\
\hline Male & 48 & 67 & & 32 & 73 & & 0.732 \\
\hline Female & 24 & 33 & & 12 & 27 & & \\
\hline Age (years) & 47 & & & 35 & & & \\
\hline \multicolumn{8}{|l|}{ Mechanism of trauma } \\
\hline Traffic accident & 48 & 67 & & 4 & 9 & & 0.004 \\
\hline Fall & 16 & 22 & & 32 & 63 & & 0.026 \\
\hline Assault & 8 & 11 & & 8 & 18 & & 0.592 \\
\hline Systolic blood pressure $(\mathrm{mmHg})$ & & & $118.06 \pm 28.97$ & & & $122.64 \pm 13.63$ & 0.631 \\
\hline Injury severity score & & & $23.0 \pm 12.0$ & & & $25.0 \pm 15$ & 0.612 \\
\hline Revised trauma score & & & $7.17 \pm 1.17$ & & & $7.39 \pm 0.62$ & 0.572 \\
\hline
\end{tabular}

MIF: Macrophage migration inhibition factor; SD: Standard deviation.

other studies; therefore, it was determined by samples from 20 healthy volunteers. The mean value of MIF from the volunteers was $588 \pm 485 \mathrm{pg} / \mathrm{mL}$.

Table I compares the baseline demographic background, clinical characteristics (systolic blood pressure, ISS, and RTS), and trauma mechanism between the elevated and normal MIF groups. No difference was observed in the general demographic backgrounds and clinical characteristics. No significant difference was observed in RTS and ISS scores between the elevated and normal MIF groups. Among the trauma mechanisms, traffic accident and a fall showed significant differences ( $p=0.004$ and 0.026 , respectively). ROC curve for MIF levels in febrile and afebrile patients are shown in Figure I. AUC for the correlation between MIF and fever was $0.738(95 \% \mathrm{Cl}$, $0.54-0.93, p=0.029)$. The cutoff value, sensitivity, and specificity of the elevated MIF level were $944 \mathrm{pg} / \mathrm{mL}, 86.7 \%$, and $64.3 \%$, respectively (Table 2 ).

MIF levels of 72 patients were elevated above the cutoff value and those of 44 patients were below the cutoff value. Of the 72 patients with an elevated MIF level, 56 were febrile, and only 8 out of the 36 patients with a normal MIF level were afebrile. Sensitivity and specificity for fever in the discriminating MIF level were $86.67 \%$ (59.5I\%-97.95\%) and $64.29 \%$ (35.18\%-87.11\%) ( $p=0.005)$. Sensitivity and specificity for CRP in the discriminating MIF level were $66.67 \%(43.04 \%-$ $85.35 \%)$ and $57.14 \%(18.75 \%-89.58 \%)(p=0.076)$ (Table 3).

The mean value of CRP (121.08 \pm 104.14$)$ was higher in the patients with an elevated MIF level than that $(49.60 \pm 47.04)$ in the patients with a normal MIF level $(p=0.04)$. Although the difference was not significant, the mean number of days of stay in the ICU was longer in the patients with elevated MIF levels $(5.67 \pm 9.5 \mathrm{I})$ than that $(2.09 \pm 2.26)$ in the patients with normal MIF levels $(p=0.233)$ (Table 4).

\section{DISCUSSION}

To the best of our knowledge, our prospective study is believed to be the first to analyze the relationship between MIF level and infection in trauma patients. MIF levels were

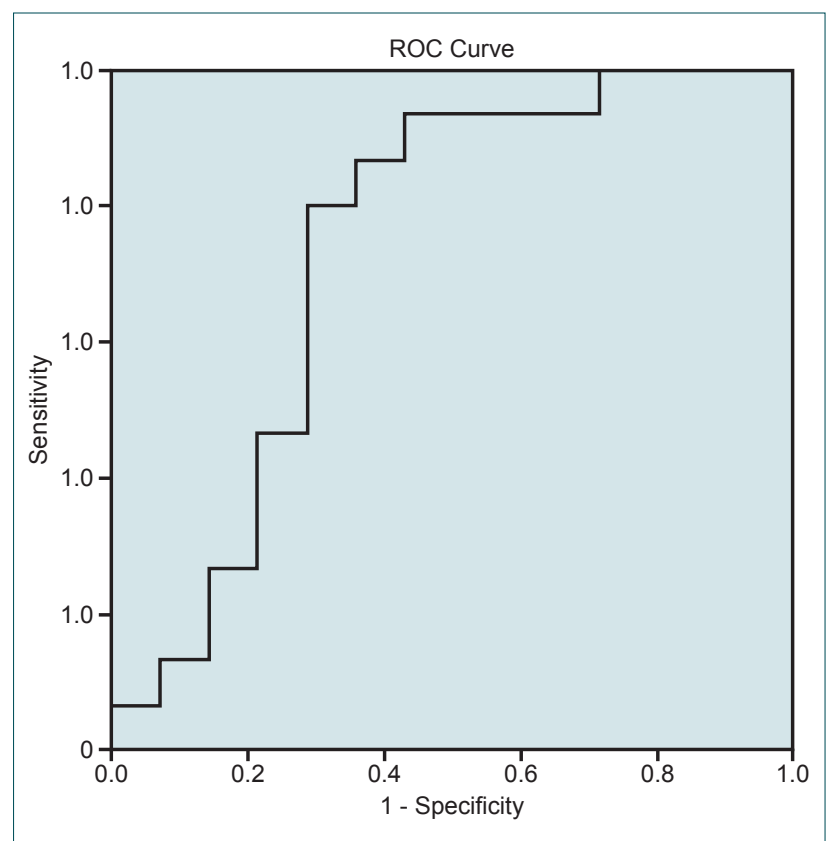

Figure 1. The receiver operating characteristics (ROC) curve was used to assess the cutoff value of MIF levels in patients with fever. The area under the ROC curve (AUC) for the correlation of MIF and fever was $0.738(95 \% \mathrm{Cl}, 0.54-0.93, \mathrm{p}=0.029)$. 
Table 2. Coordinates of the curve

\begin{tabular}{ccc}
\hline \multicolumn{3}{c}{ Test result variable(s): Macrophage migration inhibition factor } \\
\hline Positive if greater than or equal to ${ }^{\mathbf{a}}$ & Sensitivity (\%) & Specificity (\%) \\
\hline 740 & 93.3 & 58.1 \\
833 & 93.3 & 58.1 \\
944 & 86.7 & 64.3 \\
1042 & 80.0 & 64.3 \\
1125 & 80.0 & 72.4 \\
\hline
\end{tabular}

aThe smallest cutoff value is the minimum observed test value minus I, and the largest cutoff value is the maximum observed test value plus I. All the other cutoff values are the averages of two consecutive ordered observed test values.

Table 3. Sensitivities and specificities of a fever and C-reactive protein

\begin{tabular}{lcc}
\hline & Macrophage migration inhibition factor value & p \\
\hline Fever & & \\
$\quad$ Sensitivity $(95 \% \mathrm{Cl})$ & $86.67 \%(59.51 \%-97.95 \%)$ & 0.005 \\
Specificity $(95 \% \mathrm{Cl})$ & $64.29 \%(35.18 \%-87.11 \%)$ & \\
C-reactive protein & & 0.076 \\
Sensitivity $(95 \% \mathrm{Cl})$ & $66.67 \%(43.04 \%-85.35 \%)$ & \\
Specificity $(95 \% \mathrm{Cl})$ & $57.14 \%(18.75 \%-89.58 \%)$ &
\end{tabular}

Table 4. Mean values of C-reactive protein and length of stay in the intensive care unit

\begin{tabular}{|c|c|c|c|}
\hline & Elevated MIF & Normal MIF & $\mathbf{p}$ \\
\hline & Mean \pm SD & Mean $\pm S D$ & \\
\hline C-reactive protein (mg/L) & $121.08 \pm 104.14$ & $49.60 \pm 47.04$ & 0.043 \\
\hline Length of stay in Intensive care unit (days) & $5.67 \pm 9.51$ & $2.09 \pm 2.26$ & 0.233 \\
\hline
\end{tabular}

measured in a cohort of 116 trauma patients who required a complete body CT and trauma team activation. The purpose of our study was to investigate the utility of MIF for the prediction of a poor prognosis, even as serious as death, because of an infection in the trauma patients. A number of studies showed a principal role of MIF in the pathophysiology of sepsis, and in our study, we demonstrated a correlation between an elevated MIF level and a delayed infection in trauma patients. MIF level had a high sensitivity and specificity in discriminating trauma patients who were more likely to have an infection. It is well known that severe trauma weakens the host immune system, and the patients become vulnerable to infections. This phenomenon can be explained by a two-hit model. There is a close relationship between systemic inflammation and the two-hit model. The priming and subsequent response to neutrophil has been closely investigated and used to explain the two-hit model. If the initial insult primes the inflammatory response, the tissue from the immune system is injured and reaches a state similar to the systemic inflammatory syndrome. At this critical point, if a proper response does not take place, the tissue becomes vulnerable to a second hit and is led to a multiple organ dysfunction syndrome (MODS). We believe that vulnerability caused by severe trauma may work as the first hit followed by the infection as the second hit. MIF plays an important role in regulating immunologic functions. ${ }^{[3,4]}$ The major cause of delayed mortality in trauma patients is MODS, resulting from a dysregulation of homeostasis and an imbalance of the immune inflammatory response. After major trauma, polymorphonuclear neutrophils, monocytes, and macrophages release a number of proinflammatory and anti-inflammatory cytokines.

Among the parameters, elevated MIF levels were positively correlated with fever, CRP, and the LOS in the ICU. Initially, 
we set the cutoff value of the elevated MIF levels with the ROC curve for patients with a fever. In this study, the patients with an elevated MIF showed higher CRP levels, and a greater proportion of patients had a fever compared with the group with normal MIF levels. None of the patients were diagnosed with an infectious disease during their hospital stay. The patients with elevated MIF levels tended to be febrile, whereas most of the patients with normal MIF levels were afebrile. We believe that a fever indicates the presence of an inflammation along with an elevated CRP. MIF functions as a chemokine-like cytokine recruiting leukocytes into inflammatory sites. ${ }^{[3]}$ Fever is usually a symptom of an underlying condition, most often an infection. Fever indicates an infection or inflammation. In an infection, fever is caused by cytokines, and such cytokines are called pyrogenic cytokines. A wide spectrum of bacterial and fungal products induces the synthesis and release of pyrogenic cytokines. A measurement of circulating cytokines in patients with fever is rarely used because the level of pyrogenic cytokines in the circulation is often below the detection limit or does not coincide with fever. ${ }^{[2]}$ In patients with low-grade fevers, the most valuable measurements are CRP level and the erythrocyte sedimentation rate. ${ }^{[22]}$ CRP is an acute-phase protein found in the blood, the levels of which rise in response to an inflammation or an infection. ${ }^{[22]}$ The major portion of CRP is produced by hepatocytes following a stimulation by interleukin 6, with an increased expression occurring within four to six hours of an inciting insult. ${ }^{[23]}$ CRP has been studied as a screening device for inflammation, as a marker for disease activity, and as a diagnostic adjunct. The values of CRP may reflect the severity of an inflammation or a tissue injury. ${ }^{[24,25]}$

Patients with an elevated MIF level tend to stay in the ICU longer than patients with a normal MIF level. However, the RTS and ISS had limited correlations with MIF levels. These findings are particularly important. The RTS is the trauma scoring system that represents the severity of trauma. It is a physiologic scoring system based on a patient's initial set of vital signs and the Glasgow coma score that has been shown to have a strong correlation with the prognosis. ${ }^{[26,27]}$ The ISS has served as a summary measure of anatomic injury since 1974 and has been incorporated in many trauma risk adjustment models to quantify the severity of an injury. ${ }^{[28]}$ The elevation of the MIF levels has a meaningful correlation with a fever and the CRP levels. Nevertheless, the RTS and ISS showed no correlation with an elevated MIF level. These results suggest that the severity of the trauma or the injury does not affect the MIF level. Also RTS and ISS scores were not significantly different in our study groups because all of the patients included in our study required a complete body CT and trauma team activation, and in such cases, all of them were severely injured. According to our results, an elevated MIF level after a certain period of time may predict whether an infection will occur or not in the trauma patients.

Among the mechanisms of trauma, the traffic accident patients' group showed higher MIF levels. Patients after a traffic accident that require a complete body $\mathrm{CT}$ and trauma team activation mostly suffer from multiple fractures along with an internal organ injury and/or head injury, in which cases the probability of an inflammation or an infection risk is even higher. On the other hand, both the fall and assaulted patients' groups tend to have isolated injuries confined to either the head or the trunk.

Our results also prove that the combined monitoring of MIF levels, a fever, and CRP may be effective in identifying trauma patients who are likely to suffer from an infection. It has a number of limitations. First, the foci of infection were not clearly identified which leading to defining some fever to an infection may lack definite evidence. Second, an association of an elevated MIF level with a longer length of the stay in ICU can be explained by a number of reasons. The trauma mechanism could be the main reason in which the traffic accidents' group with more severe injuries with an elevated MIF level probably stayed longer. Since there could be other factors that may influence the length of the stay, it is sufficient to propose that a study would need to sample many later studies using the multi-center study. However, in this study, it is sufficient to study the early suggesting MIF.

\section{Conclusion}

Our prospective study is believed to be the first to analyze the relationship between the MIF level and an infection in trauma patients, to the best of our knowledge. From this study, the patients with an elevated MIF showed higher CRP levels, and more patients had a fever compared to the normal MIF patients' group. In a place such as the department of emergency medicine, it is critical and important for emergency physicians to make proper judgments and to prepare for the worst scenario. Therefore, the utilization of the MIF level in trauma patients has a possibility for assisting emergency physicians.

\section{Acknowledgments}

This study was partially supported by Korea University grant and Basic Science Research Program through the National Research Foundation of Korea (NRF) funded by the Ministry of Education, Science and Technology (RI522002).

Conflict of interest: None declared.

\section{REFERENCES}

1. Baugh JA, Bucala R. Macrophage migration inhibitory factor. Crit Care Med 2002;30:27-5. [CrossRef]

2. Bloom BR, Bennett $B$. Mechanism of a reaction in vitro associated with delayed-type hypersensitivity. Science 1966;153:80-2. [CrossRef]

3. Bernhagen J, Krohn R, Lue H, Gregory JL, Zernecke A, Koenen RR, et al. MIF is a noncognate ligand of CXC chemokine receptors in inflammatory and atherogenic cell recruitment. Nat Med 2007;13:587-96. [CrossRef]

4. Schober A, Bernhagen J, Weber C. Chemokine-like functions of MIF in atherosclerosis. J Mol Med (Berl) 2008;86:761-70. [CrossRef] 
5. Bernhagen J, Calandra T, Mitchell RA, Martin SB, Tracey KJ, Voelter W, et al. MIF is a pituitary-derived cytokine that potentiates lethal endotoxaemia. Nature 1993;365:756-9. [CrossRef]

6. Bacher M, Metz CN, Calandra T, Mayer K, Chesney J, Lohoff M, et al. An essential regulatory role for macrophage migration inhibitory factor in T-cell activation. Proc Natl Acad Sci U S A 1996;93:7849-54. [CrossRef]

7. Onodera S, Suzuki K, Matsuno T, Kaneda K, Takagi M, Nishihira J. Macrophage migration inhibitory factor induces phagocytosis of foreign particles by macrophages in autocrine and paracrine fashion. Immunology 1997;92:131-7. [CrossRef]

8. Abe R, Peng T, Sailors J, Bucala R, Metz CN. Regulation of the CTL response by macrophage migration inhibitory factor. J Immunol 2001;16:747-53. [CrossRef]

9. Calandra T, Bernhagen J, Metz CN, Spiegel LA, Bacher M, Donnelly T, et al. MIF as a glucocorticoid-induced modulator of cytokine production. Nature 1995;377:68-71. [CrossRef]

10. Waeber G, Calandra T, Roduit R, Haefliger JA, Bonny C, Thompson N, et al. Insulin secretion is regulated by the glucose-dependent production of islet beta cell macrophage migration inhibitory factor. Proc Natl Acad Sci U S A 1997;94:4782-7. [CrossRef]

11. Bacher M, Meinhardt A, Lan HY, Dhabhar FS, Mu W, Metz CN, et al. MIF expression in the rat brain: implications for neuronal function. Mol Med 199;4:217-30.

12. Donnelly SC, Haslett C, Reid PT, Grant IS, Wallace WA, Metz CN, et al. Regulatory role for macrophage migration inhibitory factor in acute respiratory distress syndrome. Nat Med 1997;3:320-3. [CrossRef]

13. Daun JM, Cannon JG. Macrophage migration inhibitory factor antagonizes hydrocortisone-induced increases in cytosolic IkappaBalpha. Am J Physiol Regul Integr Comp Physiol 2000;279(3):R1043-9.

14. Calandra T, Roger T. Macrophage migration inhibitory factor: a regulator of innate immunity. Nat Rev Immunol 2003;3:791-800. [CrossRef]

15. Froidevaux C, Roger T, Martin C, Glauser MP, Calandra T. Macrophage migration inhibitory factor and innate immune responses to bacterial infections. Crit Care Med 2001;29(7 Suppl):13-5. [CrossRef]

16. Bozza M, Satoskar AR, Lin G, Lu B, Humbles AA, Gerard C, David JR. Targeted disruption of migration inhibitory factor gene reveals its critical role in sepsis. J Exp Med 1999;189:341-6. [CrossRef]
17. Calandra T, Echtenacher B, Roy DL, Pugin J, Metz CN, Hültner L, et al. Protection from septic shock by neutralization of macrophage migration inhibitory factor. Nat Med 2000;6:164-70. [CrossRef]

18. Calandra T, Spiegel LA, Metz CN, Bucala R. Macrophage migration inhibitory factor is a critical mediator of the activation of immune cells by exotoxins of Gram-positive bacteria. Proc Natl Acad Sci U S A 1998;95:11383-8. [CrossRef]

19. Tohyama S, Onodera S, Tohyama H, Yasuda K, Nishihira J, Mizue Y, et al. A novel DNA vaccine-targeting macrophage migration inhibitory factor improves the survival of mice with sepsis. Gene Ther 2008;15:151322. [CrossRef]

20. Bernhagen J, Calandra T, Bucala R. Regulation of the immune response by macrophage migration inhibitory factor: biological and structural features. J Mol Med (Berl) 1998;76:151-61. [CrossRef]

21. Chen JS, Changchien CR, Tang R. Postoperative fever and survival in patients after open resection for colorectal cancer: a long-term followup study of 2,311 prospectively enrolled patients. Dis Colon Rectum 2008;51:1649-55. [CrossRef]

22. Thompson D, Pepys MB, Wood SP. The physiological structure of human C-reactive protein and its complex with phosphocholine. Structure 1999;7:169-77. [CrossRef]

23. Mackenzie I, Woodhouse J. C-reactive protein concentrations during bacteraemia: A comparison between patients with and without liver dysfunction. Intensive Care Med 2006;32:1344-51. [CrossRef]

24. van der Meer V, Neven AK, van den Broek PJ, Assendelft WJ. Diagnostic value of $C$ reactive protein in infections of the lower respiratory tract: systematic review. BMJ 2005;331:26. [CrossRef]

25. Ranzani OT, Zampieri FG, Forte DN, Azevedo LC, Park M. C-reactive protein/albumin ratio predicts 90 -day mortality of septic patients. PLoS One 2013;8:59321. [CrossRef]

26. Champion HR, Sacco WJ, Carnazzo AJ, Copes W, Fouty WJ. Trauma score. Crit Care Med 1981;9:672-6. [CrossRef]

27. Champion HR, Sacco WJ, Copes WS, Gann DS, Gennarelli TA, Flanagan ME. A revision of the Trauma Score. J Trauma 1988;29:623-9.

28. Baker SP, O'Neill B, Haddon W Jr, Long WB. The injury severity score: a method for describing patients with multiple injuries and evaluating emergency care. J Trauma 1974;14:187-96. [CrossRef]

\title{
ORIJINAL ÇALIŞMA - ÖZET
}

\section{Travma hastalarında makrofaj migrasyonunu inhibe edici faktör düzeyleri enfeksiyonla koreledir \\ Dr. Young-Duck Cho, ${ }^{1}$ Dr. Sung-Hyuk Choi, ${ }^{1}$ Dr. Jung-Youn Kim, ${ }^{1}$ Dr. Sung-Jun Park, Dr. Young-Hoon Yoon, ${ }^{1}$ Dr. Han-Jin Cho, ${ }^{2}$ Dr. Ji-Won Yeom ${ }^{3}$}

\author{
${ }^{1}$ Kore Üniversitesi Guro Hastanesi, Acil Tıp Bölümü, Seul-Güney Kore \\ ${ }^{2}$ Kore Üniversitesi Ansan Hastanesi, Acil Tıp Bölümü, Ansan, Kyunggi-do-Güney Kore \\ ${ }^{3}$ Kore Üniversitesi Tıp Koleji, Seul-Güney Kore
}

AMAÇ: Migrasyon inhibe edici faktörün (MiF) rolü en iyi septik şok ve septik hastalıkta anlaşılır. Ancak travmayla ilişkili enfeksiyonda MiF'nin rolü henüz tam olarak incelenmemiştir. Bu çalışmada, travma hastalarında MiF'nin rolü değerlendirildi.

GEREÇ VE YÖNTEM: Çalışma popülasyonu MiF düzeyleri sonuçlarına göre iki gruba ayrıldı. Gruplar arasında başlangıçta MiF düzeyleri, travmanın mekanizması, gözden geçirilmiş travma skoru (RTS), sağkalım oranı, yoğun bakım ünitesinde (YBÜ) kalış süresi, lökosit sayıları ve C-reaktif protein (CRP) düzeyleri karşılaştırıldı.

BULGULAR: Çalışmaya I Ağustos 2014 ile 3I Temmuz 2015 arasında toplam II 6 hasta alındı. Yüksek MiF'li grupta ortalama YBÜ'de kalış süresi $5.67 \pm 7.54$ gün iken normal MiF düzeyli grupta $2.09 \pm 2.26$ gün idi. Yine yüksek MiF'li grupta CRP düzeyi normal MiF'li gruptakinden daha yüksekti. TARTıŞMA: Acil tıp departmanı gibi bir bölümde acil hekimlerin en kötü senaryoya göre uygun yargıda bulunması ve hazırlıklı olması kritik değer ve önem taşır. Bu nedenle, travma hastalarında MiF düzeyinin kullanılması acil hekimlerine ipuçları verme olasılığına sahiptir. Anahtar sözcükler: Enfeksiyon; makrofaj migrasyonunu inhibe edici faktör; travma.

Ulus Travma Acil Cerrahi Derg 2017;23(3):193-198 doi: 10.5505/tjtes.2016.04780 